\title{
Potential changes in Korean water resources estimated by high-resolution climate simulation
}

\author{
Deg-Hyo Bae ${ }^{1, *}$, Il Won Jung ${ }^{1}$, Heejun Chang ${ }^{2}$ \\ ${ }^{1}$ Department of Civil \& Environmental Engineering, Sejong University, 98 Kunja-Dong, Kwangjin-Gu, Seoul 143-747, Korea \\ ${ }^{2}$ Department of Geography, Portland State University, 1721 SW Broadway, Portland, Oregon 97201, USA
}

\begin{abstract}
Because climate change does not occur uniformly throughout the globe, climate change is expected to impact each region differently. Undertaking the first national-level climate impact assessment in Korea, we evaluated the impacts of climate change on Korea's 139 drainage subbasins, that have varying climate and complex topography. Subsequently, we estimated the spatial and temporal variations of water resources in each sub-basin under a climate change simulation. This simulation was based on high-resolution data $(27 \times 27 \mathrm{~km})$ that were created by the Korean Meteorological Research Institute using the climate models ECHO-G and NCAR/MM5. In order to generate the climate and runoff simulations for each sub-basin, we used the LARS-WG model, a stochastic weather generator, and the PRMS hydrologic model. The results indicated that the amount of runoff was expected to decrease in spring and summer and to increase in fall and winter. Runoff amounts were also expected to increase in northern regions and decrease in southern regions. In addition, relative changes in water balance components - precipitation, evapotranspiration, and runoff-are investigated. These variations in the timing and amount of runoff under climate change could have significant implications for the sustainable management of water resources in Korea.
\end{abstract}

KEY WORDS: Climate-change impact - Water resources $\cdot$ Hydrological model $\cdot$ Regionalization . Korea

Resale or republication not permitted without written consent of the publisher

\section{INTRODUCTION}

Changes in temperature and precipitation patterns resulting from changes in climate are expected to impact the spatial and temporal distribution of water resources (IPCC 2007). Global assessments of freshwater resources show increasing water stresses under climate change and population growth scenarios in many parts of the world, including East Asia (Arnell 2004, Milly et al. 2005). Such impacts are expected to show larger variation regionally than globally. The spatial variation of precipitation due to climate change largely depends on climatic and geographical characteristics of the region (Drogue et al. 2004). Many countries have already estimated the variation of water resources using climate-change scenarios based on global climate model (GCM) simulations (Fowler 1999, Bergström et al. 2001, Graves \& Chang 2007). These studies have shown that climate-change impacts on water resources may differ by region, depending on regional geographic characteristics and climate conditions. For example, Pilling \& Jones (1999) found higher rates of runoff in the wetter, northern part of Britain, than the drier, south-eastern region. They projected that winter runoff would increase the most in northern Britain, whilst summer runoff would experience major reductions over large parts of England and Wales by 2050 and 2065 as compared to the reference period (1961 to 1990). Therefore, in northern regions, flood damage in winter is expected to rise due to increased precipitation and runoff. A study on China also found differences in the degree of changes and tendencies of precipitation and runoff among 82 sub-basins (Guo et al. 2002).

South Korea faces future problems in securing sustainable water resources (PAI 1993) and is expected to suffer a water shortage of approximately 1.8 billion $\mathrm{t}$ around 2011 (MOCT 2001). Thus, a reliable estimate of the variation and vulnerability of Korean water re- 
sources in the face of climate change is essential for future water resource planning. While several studies have assessed the climate-change impact on Korean water resources, they addressed the impact for a particular river basin (e.g. Ahn et al. 2001, Kim et al. 2005). As yet, there has been no assessment for the entire Korean peninsula. We seek to fill this gap by quantifying the potential changes in the timing and magnitude of precipitation and runoff for all sub-basins of South Korea.

South Korea (area: $996000 \mathrm{~km}^{2}$; population: 47250000 ) has a monsoon climate and varying geographical characteristics, leading to a regionally diverse climate. Thus, to effectively assess the impacts of climate change, a high-resolution simulation is required to accurately reflect regional climate characteristics (IPCC 2007). We analyzed the spatial and temporal variations in region-specific water resources of Korea using a high-resolution climate-change simulation. As the most comprehensive study to date into the impact of climate change on runoff in Korea, we used 139 subbasins of 5 major river basins for $90 \mathrm{yr}$ during the 21st century. The climate-change simulation developed by the Korean Meteorological Research Institute (METRI) was based on the A2 greenhouse gas emission scenario of the IPCC SRES (Intergovernmental Panel on Climate Change Special Report on Emissions Scenario; IPCC 2007). Global simulations were dynamically downscaled to a $27 \times 27 \mathrm{~km}$ grid resolution (METRI 2004). To assess changes in runoff amount and timing, we used a physically based model, the Precipitation Runoff Modeling System (PRMS) developed by the United States Geological Survey (USGS) (Leavesley et al. 1983, 2002).

\section{METHODOLOGY}

The formulation of basin-scale high-resolution climate projections and the corresponding hydrologic analysis were required for an appropriate climatechange impact assessment on water resources. Fig. 1 illustrates the methodology adopted in this study, which made use of long-term precipitation and temperature simulations. These simulations were used as input to the impact-assessment model to generate hydrological projections for each basin. Finally, we used the results for each sub-basin to estimate the spatial and temporal water balance variations.

\subsection{High-resolution simulations}

Despite rapid advances in the development of GCMs, their outputs generally show some biases in the simulation of climate data. Temperature is generally well represented, but precipitation less so. At small scales, these biases are often so large that the direct application of the modeled precipitation to a macroscale hydrological model is not feasible (IPCC 2007). It is particularly problematic to directly apply the output of the simulation from GCMs (Khan et al. 2006) to a region with varied climate characteristics resulting from strong orographic differences. In coarse scale GCMs, the territory of South Korea is expressed as ocean instead of land, and much uncertainty stems from the limitations of the physical parameterization of the model. Therefore, a transfer function is required to generate the climate information on a detailed timespace scale.

METRI adopted a dynamic downscaling technique to provide future regional climate information using the regional climate model (RCM) MM5 (Pennsylvania State University/National Center for Atmospheric Research mesoscale model) from the AtmosphereOcean General Circulation Model (AOGCM) ECHO-G (Max-Planck Institute for Meteorology Models and Data Group). ECHO-G is a coupled model composed of the atmospheric part (ECHAM4) and the oceanic part (HOPE-G). This model is used for climate simulation, based on the future greenhouse gas emission scenario of the IPCC SRES A2 (METRI 2004). For a more detailed explanation of ECHO-G, see Legutke \& Maire-Reimer (1999). METRI used the output of ECHO-G, calculated at $350 \mathrm{~km}$ resolution, as the initial and boundary conditions of a RCM in order to produce a high-resolution climate change scenario at a horizontal resolution of $27 \times 27 \mathrm{~km}$. The transient simulations with MM5 span the whole period between 1960 and 2100. In order to take the complicated geography of the Korean peninsula into account, the topography and land use data appropriate to the horizontal resolution of the RCM were used.

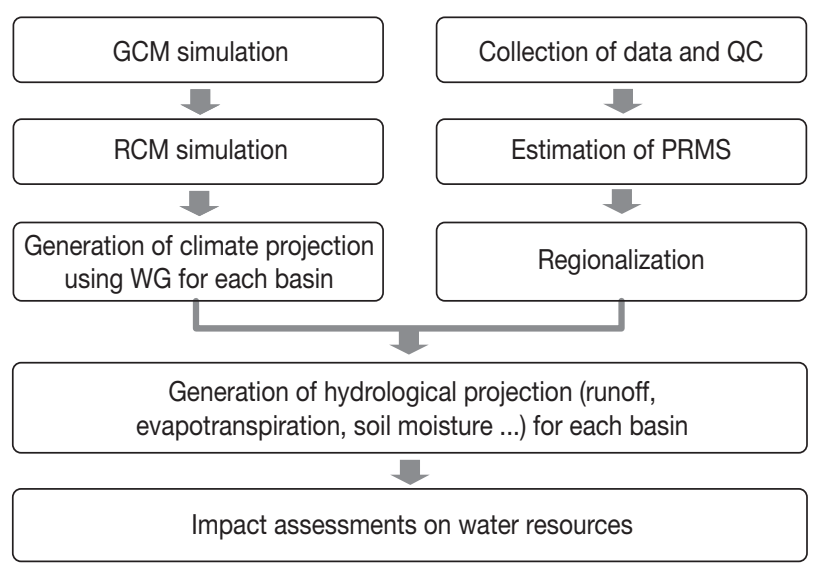

Fig. 1. Scheme for climate change impact assessments on water resources. GCM: global climate model; RCM: regional climate model; WG: weather generator; QC: quality control; PRMS: Precipitation Runoff Modeling system 


\subsection{Weather generator}

A weather generator can serve as a computationally inexpensive tool to produce a realistic climate simulation - in a statistical sense - based on observed data at a daily timescale, incorporating changes in the mean and in variations in this data (Semenov \& Barrow 2002). A typical weather generator is the LARS-WG stochastic weather generator that was developed to estimate the climate data for regions that either have not been surveyed or lack measurement. This weather generator also has been applied in several recent climate studies (e.g. Leander et al. 2005, Khan et al. 2006). It generates a suite of climate variables, including precipitation, maximum and minimum temperatures, and solar radiation. The simulation of precipitation occurrence is based on distributions of the amount of precipitation and the length of consecutive wet and dry days. Observed daily climate data are required to calculate the site-specific weather parameters to generate the synthetic data (Semenov \& Barrow 2002). In this study, the LARS-WG was calibrated using the observed weather data, and the performance of the weather generator was verified using the $t$-test and $F$-test. In order to obtain the parameters of the LARS-WG, the 56 weather stations are used (Fig. 2).

\subsection{Hydrologic model}

In order to produce hydrologic information from the climate simulations, we selected PRMS, a physically-based deterministic hydrologic model. PRMS is a distributed-parameter hydrologic model that represents local watershed characteristics by partitioning a watershed into 'homogeneous' units known as hydrologic response units (HRUs). HRUs help preserve the heterogeneity of the physiographic properties of the drainage basin, and can be used for regional hydrological modeling in different climatic regions (Dagnachew et al. 2003). PRMS was developed to simulate runoff under a wide range of hydrologic conditions, making it ideal for the geographically diverse basins of Korea (Jung \& Bae 2005a).

The PRMS is designed to analyze the effects of precipitation, temperature, and land use on river discharge and general basin hydrology. The model generates a water-energy balance for each component of the hydrologic cycle for each time step during the simulation. The input variables of the model are daily precipitation and minimum and maximum daily air temperatures. Many equations contained in the model formulation include coefficients that can be estimated directly from known or measurable basin characteristics (Leavesley et al. 2002). Only a few empirical parameter values can actually be estimated from the observed hydrologic data (Table 1). These parameters are primarily associated with surface runoff, and subsurface and groundwater reservoir computations. For quantitative climate-change impacts on water resources, a reasonable estimation of evapotranspiration is also required. The Hamon method (Hamon 1961) is used to calculate evapotranspiration in the PRMS model. This methodology uses the number of daylight hours and daily temperature to calculate potential evapotranspiration. The PRMS model has been used in climate change assessments for many river basins (e.g. Hay et al. 2002, Dagnachew et al. 2003).

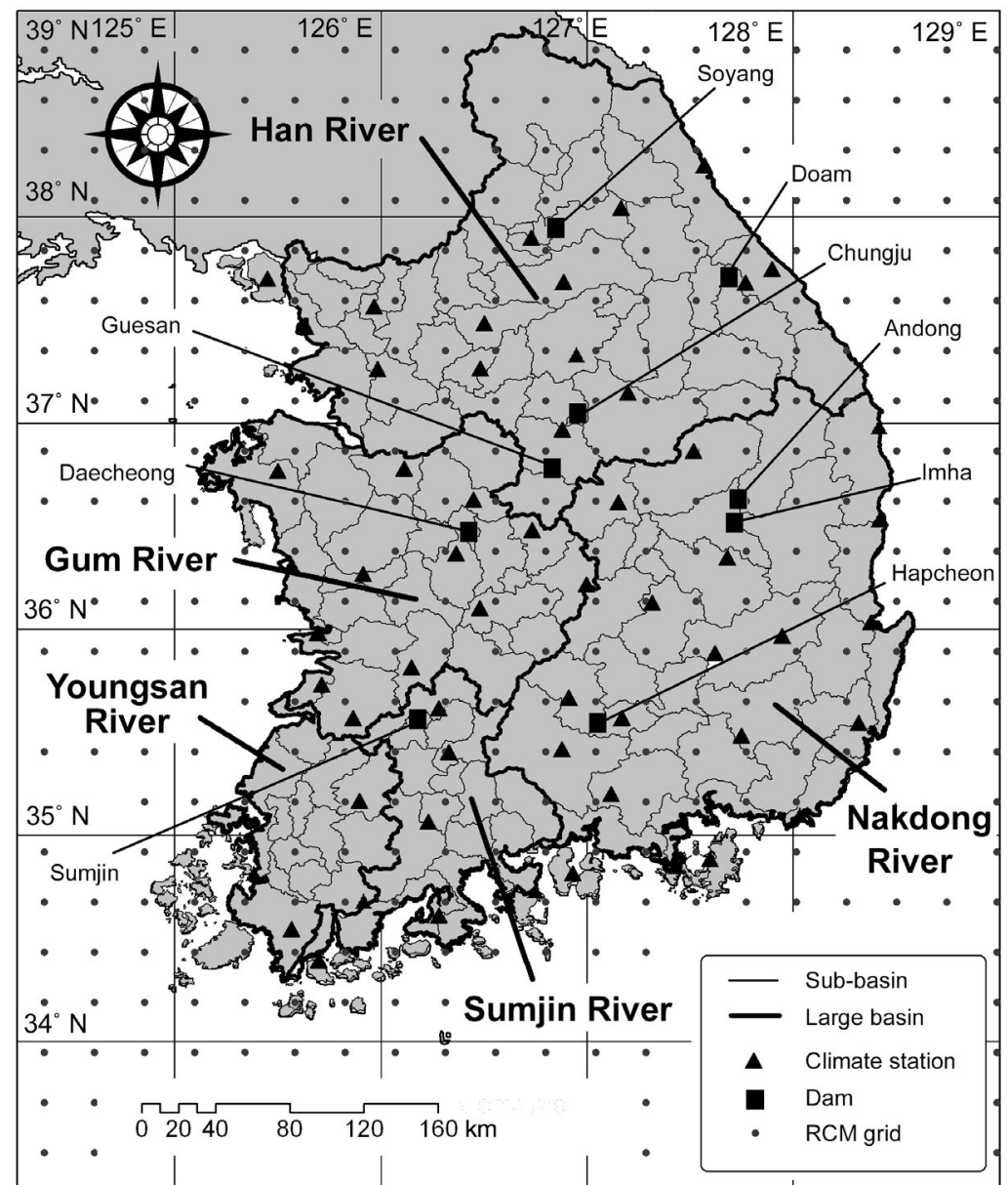

Fig. 2. Location of the 139 sub-basins of the 5 major river basins of South Korea, and the 56 weather stations used 
Table 1. Description and range of estimated or optimized $\left(^{*}\right)$ parameters in the PRMS model. Optimized parameters based on the Rosenbrock method (Rosenbrock 1960). HRU: hydrologic response unit. Source data-D: Digital elevation map; V: Vegetation map; S: Soil map; L: Land use map

\begin{tabular}{|c|c|c|c|}
\hline Parameter & Description & Range & Source data \\
\hline hru_elev & Mean elevation for each HRU, in feet & $-300-30000$ & $\mathrm{D}$ \\
\hline hru_slope & HRU slope in decimal vertical feet / horizontal feet & $0-10$ & $\mathrm{D}$ \\
\hline cov_type & Cover type $(0=$ bare, $1=$ grasses, $2=$ shrubs, $3=$ trees $)$ & $0-3$ & $\mathrm{~V}$ \\
\hline covden_sum & Summer vegetation cover density & $0-1$ & $\mathrm{~V}$ \\
\hline covden_win & Winter vegetation cover density & $0-1$ & $\mathrm{~V}$ \\
\hline wrain_intcp & Winter rain interception storage capacity, in inches & $0-5$ & $\mathrm{~V}$ \\
\hline srain_intcp & Summer rain interception storage capacity, in inches & $0-5$ & $\mathrm{~V}$ \\
\hline snow_intcp & Winter snow interception storage capacity, in inches & $0-5$ & $\mathrm{~V}$ \\
\hline soil_type & HRU soil type ( 1 = sand, 2 = loam, 3 = clay $)$ & $1-3$ & $\mathrm{~S}$ \\
\hline soil_moist_max & Maximum available water holding capacity in soil profile, in $\mathrm{mm}$ & $0-20$ & $\mathrm{~S}$ \\
\hline soil_rechr_max & Maximum available water holding capacity for soil recharge zone, in mm & $0-10$ & $\mathrm{~S}$ \\
\hline hru_percent_imperv & HRU impervious area, in decimal percent & $0-1$ & $\mathrm{~L}$ \\
\hline smidx_coef* & Coefficient in contributing area computations & $0.0001-1$ & \\
\hline smidx_exp ${ }^{*}$ & Exponent coefficient in contributing area computations & $0.2-0.8$ & \\
\hline ssrcoef_lin** & Coefficient to route subsurface storage to streamflow & $0.0-1.0$ & \\
\hline ssrcoef_sq* ${ }^{*}$ & Non-linear coefficient to route subsurface storage to streamflow & $0.0-1.0$ & \\
\hline ssr2gw_exp* & Exponent coefficient to route water from subsurface to groundwater & $0.0-3.0$ & \\
\hline ssr2gw_rate* & Coefficient to route water from subsurface to groundwater & $0.0-1.0$ & \\
\hline soil2gw_max* & Maximum amount of the soil water excess to groundwater each day & $0.0-5.0$ & \\
\hline gwflow_coef* ${ }^{*}$ & Groundwater reservoir recession coefficient & $0.0-1.0$ & \\
\hline Hamon_coef* ${ }^{*}$ & Hamon evapotranspiration coefficient & $0.004-0.008$ & \\
\hline
\end{tabular}

\subsection{Regionalization method}

Early attempts to model ungauged catchments simply used the hydrological model parameter values derived for neighboring catchments where discharge data were available, i.e. a geographical proximity approach (Wagener \& Wheater 2006). However, this method is insufficient, because even nearby catchments can be very different with respect to their hydrological behaviors (Beven 2000). One of the most common approaches to model runoff for ungauged catchments is to relate model parameters and catchment characteristics in a statistical manner (e.g. Merz \& Blöschl 2004), assuming that the unique characteristics of each catchment can be captured. This methodology calibrates specific model parameters to as large a number of gauged catchments as possible and calculates relationships between model parameters and catchment characteristics. These statistical relationships and the measurable properties of the ungauged catchments can then be used to determine the estimates of model parameters in ungauged catchments. This procedure is usually referred to as regionalization or spatial generalization (e.g. Lamb \& Calver 2002). This method requires a large number of gauged catchments. However, this regionalization method cannot be directly applied in Korean river basins, because there are only a few basins that have flow-gauging stations with natural and highly reliable long-term discharge data.

The regionalization method used in the present study employs a multiple regression equation, describing the relationship between basin geographical data and observed discharge data. This method is based on the configuration of basin characteristics and river discharges at a drainage basin outlet. In other words, the river flows at a certain location of the basin are affected by basin characteristics such as basin area, basin slope, river length, soil type, percentage of forest cover, etc. (e.g. Koren et al. 2000, Atkinson et al. 2002). Once the correlation between observed river flows and basin characteristics is calculated for calibration basins, the model parameters of ungauged basins are regionalized from the relationship between the river flow and catchment characteristics for the calibration basins (Jung \& Bae 2005b). In this way, model parameters of ungauged basins are derived from gauged basins with similar flow characteristics (Table 1). In the present study, we first determined the physical characteristics of each sub-basin, such as the maximum available soil water-holding capacity (SM), average basin slope (SL), and area ratio of forest in a watershed (LU) from GIS data layers (obtained from the Water Management Information System, WAMIS: http://www.wamis.go.kr, [in Korean]). The estimated discharge $(Q)$ was then determined for ungauged catchments using Eq. (1) (Jung \& Bae 2005b).

$$
Q=83.1 \times \mathrm{SM}^{-2.57} \times \mathrm{SL}^{0.51} \times \mathrm{LU}^{-0.03}
$$

After comparing the estimated discharge in ungauged catchments and observed discharge in the selected gauged watersheds (i.e. calibration catchments), we then selected the PRMS model parameters for the ungauged watersheds based on the closely related river discharge regimes. 


\section{GENERATION OF BASIN-SCALE HYDROLOGICAL PROJECTION}

\subsection{Study area and data}

Korea is made up of five large river basins (the Han River, the Nakdong River, the Gum River, the Sumjin River, and the Youngsan River) as shown in Fig. 2. In order to determine the regional climate change impact on water resources, we divided the Han, the Nakdong, the Gum, the Sumjin and the Youngsan River basins into $47,33,27,17$ and 15 sub-basins, respectively, totalling 139 sub-basins. The areas of the sub-basins are in the range of 43 to $2293 \mathrm{~km}^{2}$, with a mean of $\sim 700 \mathrm{~km}^{2}$.

We obtained GIS data sets for soil type, vegetation cover, land use data and orography (Digital Elevation Model, DEM) from WAMIS. In order to obtain river discharge, we compiled climate data and the inflow volumes at the selected study area (Table 2). For the calibration of the parameters of LARS-WG, we used the 56 weather stations that contain daily data for a period of $>28 \mathrm{yr}$. The data were provided by the Korea Meteorological Administration and the Korea Ministry of Construction and Transportation.

Table 2. General information on the study area

\begin{tabular}{|lcccc|}
\hline Watershed & Area & $\begin{array}{c}\text { Mean } \\
\text { elevation } \\
(\mathrm{m})\end{array}$ & $\begin{array}{c}\text { Mean } \\
\text { slope } \\
(\%)\end{array}$ & $\begin{array}{c}\text { Annual mean } \\
\text { precipitation } \\
(\mathrm{mm})\end{array}$ \\
\hline \multicolumn{2}{l}{ Calibration sites } \\
Doam & 149.4 & 915.1 & 32.62 & 1489.6 \\
Guesan & 676.7 & 357.4 & 36.87 & 1133.7 \\
Andong & 1590.7 & 557.3 & 42.39 & 1057.9 \\
Imha & 1367.7 & 394.7 & 40.35 & 951.6 \\
Hapcheon & 928.9 & 504.6 & 34.87 & 1444.6 \\
Sumjin & 763.5 & 359.3 & 17.52 & 1315.9 \\
Verification sites & & & \\
Soyang & 2694.4 & 650.5 & 45.97 & 1185.4 \\
Chungju & 6661.6 & 609.1 & 34.89 & 1199.4 \\
Daecheong & 4190.5 & 363.0 & 18.94 & 1177.5 \\
\hline \multicolumn{5}{l}{} \\
\hline
\end{tabular}

\subsection{Estimation of hydrologic model parameters}

\subsubsection{Gauged catchments}

In order to provide runoff values that reflect natural flows, the PRMS model was calibrated and verified on the basis of the historical daily river discharges observed at 9 gauges located upstream of dam sites. The first twelve variables in Table 1 were derived from GIS analysis for each basin by using DEM, land use, vegetation cover, and soil layer maps. The remaining nine parameters were estimated in the PRMS model using the Rosenbrock optimization method (Rosenbrock 1960). The historical river discharge data collected for each sub-basin was divided into a calibration period and a verification period (Table 3 ). Then, the parameters were estimated for the calibration period, and the suitability of the estimated parameters was verified for the verification period. Table 3 shows the summary statistics of the simulation periods. The statistical analyses used were as follows:

$$
\begin{aligned}
\text { Correlation coefficient }(\mathrm{r}) & =\mathrm{SS}_{O S} / \sqrt{\mathrm{SS}_{O} \times \mathrm{SS}_{S}} \\
\mathrm{SS}_{O S} & =\Sigma\left(O_{i}-\bar{O}\right)\left(S_{i}-\bar{S}\right) \\
\mathrm{SS}_{O} & =\Sigma\left(O_{i}-\bar{O}\right)^{2} \\
\mathrm{SS}_{S} & =\Sigma\left(S_{i}-\bar{S}\right)^{2}
\end{aligned}
$$

where $O$ is observed flow and $S$ is simulated flow;

Root mean square error $(\mathrm{RMSE})=\sqrt{\Sigma\left(O_{i}-S_{i}\right)^{2} / \mathrm{n}}$ where $\mathrm{n}$ is a number of data;

Nash-Sutcliffe efficiency coefficient (NSE) =

$$
\left[\Sigma\left(O_{i}-\bar{O}\right)^{2}-\Sigma\left(O_{i}-S_{i}\right)^{2}\right] / \Sigma\left(O_{i}-\bar{O}\right)^{2}
$$

Percent error in volume $(\mathrm{VE})=100 \times\left(\Sigma S_{i}-\Sigma O_{i}\right) / \Sigma O_{i}$

The observed and simulated runoffs for the gauged catchments are in reasonably good agreement. For example, the maximum VE among the selected study basins is about $11 \%$ in Doam and Guesan dams. Although values determining the groundwater recharge efficiency (ssr2gw_exp, ssr2gw_rate, ssrcoeff_ lin, and soil2gw_max; see Table 1 for descriptions of these parameters) showed the biggest difference by

\begin{tabular}{|c|c|c|c|c|c|c|c|c|c|c|}
\hline \multirow{2}{*}{ Basin } & \multicolumn{5}{|c|}{ - Calibration } & \multicolumn{5}{|c|}{ - Verification } \\
\hline & Period & $\mathrm{r}$ & RMSE & NSE & VE & Period & $\mathrm{r}$ & RMSE & NSE & VE \\
\hline Doam & 1999-2001 & 0.92 & 2.55 & 0.85 & -6.03 & 1996-1998 & 0.89 & 2.24 & 0.78 & 11.46 \\
\hline Guesan & 1991-2001 & 0.84 & 3.10 & 0.69 & 8.76 & $1982-1990$ & 0.90 & 2.91 & 0.79 & -11.32 \\
\hline Andong & 1991-2001 & 0.87 & 2.23 & 0.76 & 0.31 & $1977-1990$ & 0.85 & 2.44 & 0.70 & 0.95 \\
\hline Hapcheon & 1995-2001 & 0.94 & 1.94 & 0.88 & -1.63 & 1989-1994 & 0.90 & 2.02 & 0.80 & 5.42 \\
\hline Imha & 1997-2001 & 0.88 & 2.70 & 0.77 & 1.92 & 1993-1996 & 0.80 & 2.56 & 0.64 & -5.45 \\
\hline Sumjin & 1991-2001 & 0.86 & 3.05 & 0.74 & 3.82 & $1975-1990$ & 0.72 & 4.32 & 0.51 & 7.30 \\
\hline
\end{tabular}

Table 3. Model calibration and verification period. r: correlation coefficient; RMSE: root mean square error; NSE: Nash-Sutcliffe efficiency coefficient; VE: percent error in volume 
sub-basin, the other variables did not show a noticeable difference (Table 4).

\subsubsection{Ungauged catchments}

For the simulation of long-term runoff in the PRMS model, only 9 unknown parameters needed to be regionalized (see Table 1). The other parameters were directly estimated for each basin using GIS and other relevant data (Leavesley et al. 2002). The set of 9 parameter values determined from each gauged basin was then applied to other ungauged basins using the regionalization method described in Section 2.4. In other words, all basins were categorized into one of 6 groups of basins, and the 6 different sets of the 9 parameters were applied to 6 groups of basins without further modifications (Bae et al. in press).

For evaluation of the regionalization method used in this study, we selected three ungauged sites-the Soyang, Chungju, and Daecheong dam sites (Fig. 2)as verification sites. After the estimated discharge for a particular ungauged catchment was obtained from Eq. (1), we compared the estimated discharge with the observed discharge of the calibration sites in Table 2. The PRMS model parameters for the ungauged watershed were then selected, based on the closely related river discharges. Table 5 gives the model performance statistics computed from observed and simulated river flows on the three basins. The observed monthly flows are in reasonable agreement with the simulated ones ( $r>0.81$ ). It can thus be concluded that the hydrological simulations generated by the PRMS model

Table 4. The PRMS model parameters for the Rosenbrock method. See Table 1 for parameter descriptions

\begin{tabular}{|lcccccc|}
\hline Parameter & Doam & Guesan & Andong & Hapcheon & Imha & Sumjin \\
\hline smidx_coef & 0.0025 & 0.0027 & 0.0024 & 0.0023 & 0.0024 & 0.0025 \\
smidx_exp & 0.3100 & 0.3050 & 0.3100 & 0.2800 & 0.3100 & 0.3010 \\
ssr2gw_exp & 1.3842 & 0.0012 & 0.1604 & 0.0535 & 0.0052 & 2.4473 \\
ssr2gw_rate & 0.1317 & 0.0322 & 0.0346 & 0.0844 & 0.0532 & 0.0002 \\
ssrcoef_lin & 0.0580 & 0.0054 & 0.0588 & 0.0002 & 0.0114 & 0.0006 \\
ssrcoef_sq & 0.1291 & 0.1944 & 0.2015 & 0.2287 & 0.4602 & 0.2122 \\
soil2gw_max & 0.0010 & 0.0210 & 0.0120 & 0.0100 & 0.0080 & 0.0700 \\
gwflow_coef & 0.0180 & 0.0200 & 0.0150 & 0.0100 & 0.0200 & 0.0230 \\
\hline
\end{tabular}

Table 5. Model performance statistics by the regionalization method. NSE, VE: see Table 3 for descriptions

\begin{tabular}{|lccccc|}
\hline Watershed & Data period & r & RMSE (mm/day) & NSE & VE (\%) \\
\hline Soyang & $1974-2001$ & 0.87 & 3.50 & 0.76 & 3.48 \\
Chungju & $1986-2001$ & 0.81 & 2.00 & 0.65 & 1.23 \\
Daecheong & $1981-2001$ & 0.82 & 3.00 & 0.67 & 2.64 \\
\hline
\end{tabular}

parameters determined through the regionalization method are within acceptable bounds of accuracy for ungauged sub-basins.

\subsection{Climate variables for each catchment}

The simulated monthly and seasonal precipitation data derived from the LARS-WG show no significant difference $(p>0.05)$ between the observed and simulated data (Jung et al. 2007), suggesting that the LARSWG is useful for climate change projection. In order to produce a climate change projection for each watershed, we calculated the changes in mean monthly temperature $\left({ }^{\circ} \mathrm{C}\right)$ and precipitation (decimal) for 3 periods (2001 to 2030, 2031 to 2060, and 2061 to 2090) using the A2 scenario relative to the reference period (1971 to 2000) as shown in Fig. 3. The Thiessen weighted method (Thiessen 1911) was used to calculate the amount of change at each sub-basin from the rate of change of the gridded MM5 simulation results. To produce precipitation change simulations, the LARS-WG parameters were modified, based on relative changes in both the duration of wet and dry periods and the monthly precipitation amount. Temperature change simulations were based on absolute changes in monthly temperature. Although the rate of change in the maximum and minimum temperature must be considered when generating climate change projections using the LARS-WG, we assumed that these changes would be identical to the changes in mean temperature. Therefore, only the mean temperature of the high-resolution climate simulation is used.

This assumption is based on the recent IPCC report that predicts very small changes in diurnal temperature range (IPCC 2007). The LARS-WG, calibrated at the 56 weather stations, was applied to each sub-basin based on the shortest distance from the center of the catchment to the nearest weather station.

For the reference period, the simulated annual mean precipitation derived from the MM5 and LARS-WG models was compared with the observed annual mean precipitation (Fig. 4). The results showed the MM5 RCM underestimated the annual mean precipitation for subbasins located in the Han River, Gum River, and Sumjin River basins. This indicates that the regional impact assessment on water resources using RCM may have limitations in simulating climate at the catchment scale. As shown in Fig. 4, the simulated precipitation values generated 


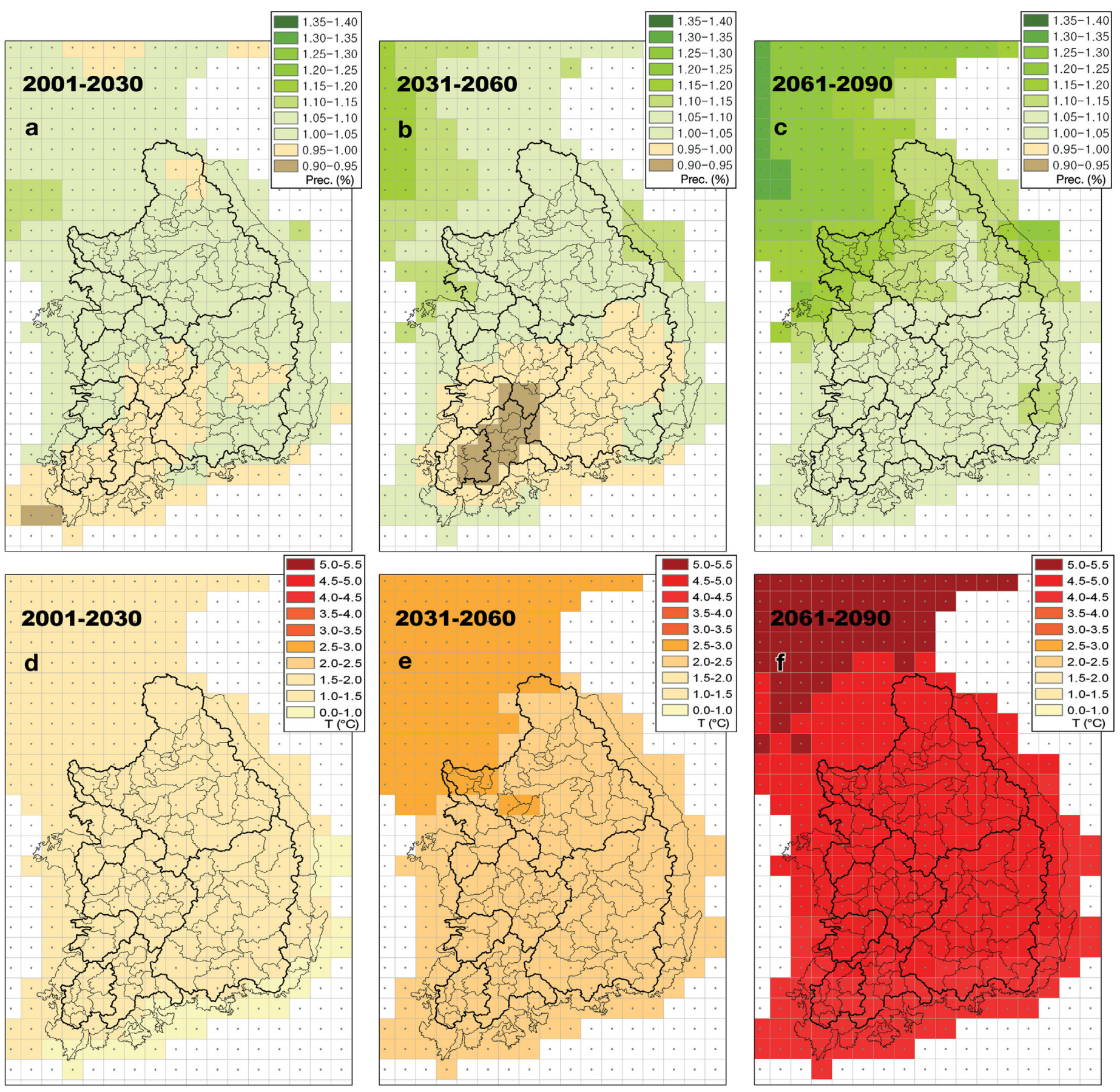

Fig. 3. (a-c) Relative changes of annual mean precipitation (decimal) and (d-e) temperature $\left({ }^{\circ} \mathrm{C}\right)$ during $(\mathrm{a}, \mathrm{d}) 2001$ to 2030 , (b,e) 2031 to 2060 and (c,f) 2061 to 2090 relative to the reference period 1971 to 2000, simulated by MM5

by LARS-WG were closer to the observed precipitation than the MM5 simulations. This shows that the direct use of the RCM output significantly underestimates the amount and timing of annual runoff. It should be noted that using the weather generator and RCM together will decrease the uncertainty of regional impact assessment on water resources.

\section{RESULTS}

\subsection{Changes in annual runoff}

Fig. 5 shows the effects on the annual runoff for each sub-basin during the study periods. The rate of change in annual mean runoff is from -12 to $+14 \%$ in 2001 to 


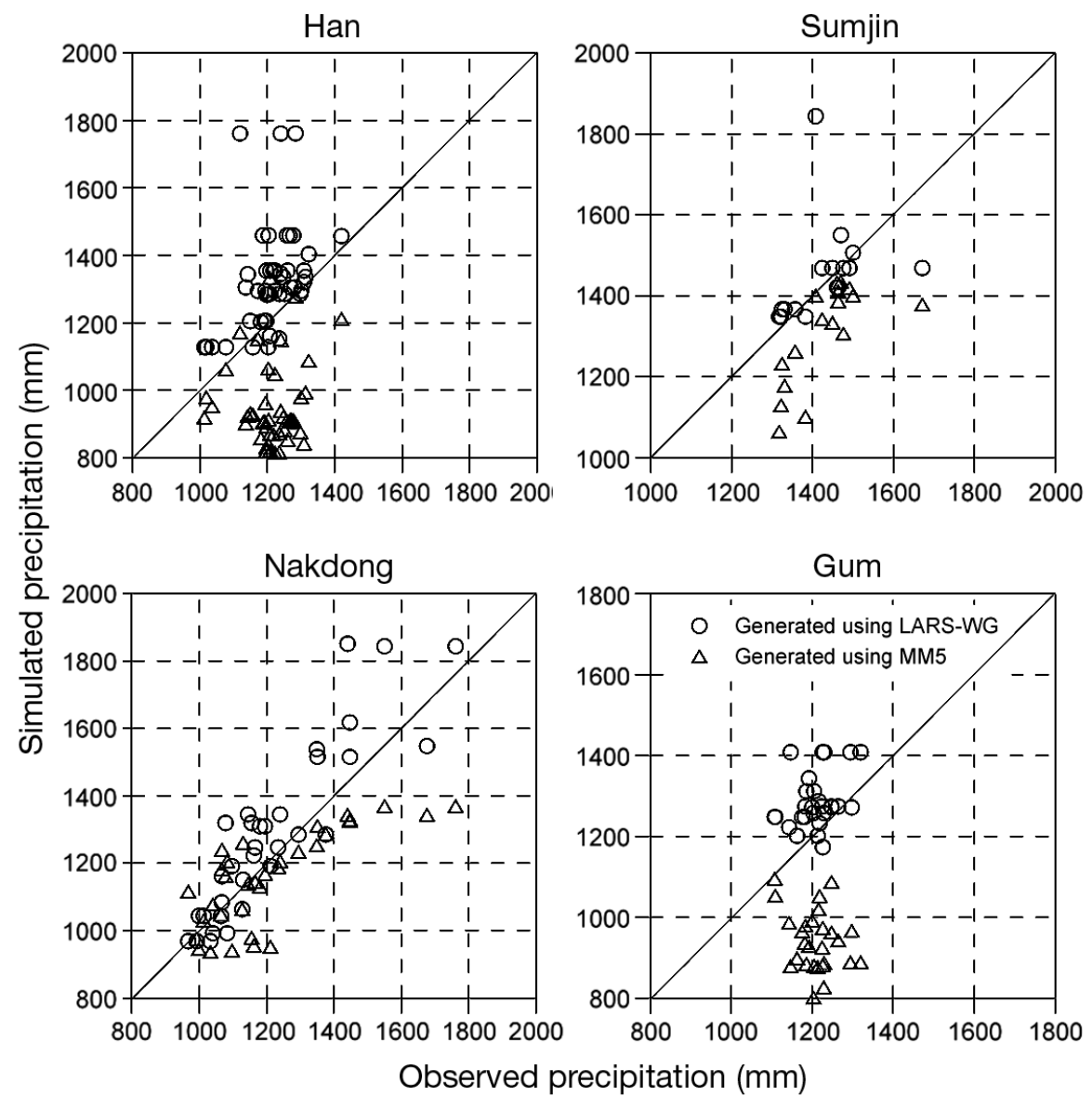

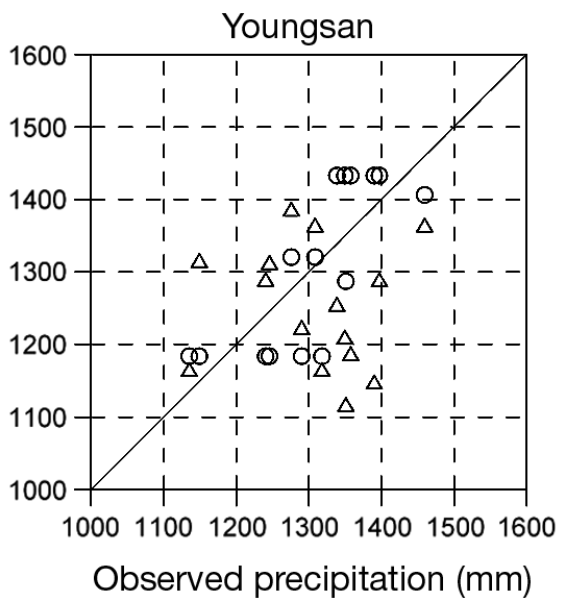

Fig. 4. Comparison of annual mean precipitation with observed and 2 generated mean areal precipitation values (LARS-WG: O; MM5: $\Delta$ ) at each river basin
$2030,-23$ to $+16 \%$ in 2031 to 2060 , and -14 to $+20 \%$ in 2061 to 2090 . In the 2001 to 2030 period, the simulation projected annual mean runoff increases in the subbasins of the Han River, the east coast, the lower region of the Nakdong River, and the northern region of the Gum River. In the remaining sub-basins, annual mean runoff was projected to decrease. In 2031 to 2060, the annual mean runoff was projected to decrease in most of the basins except for downstream sub-basins of the Han River and portions of the east coast. Sub-basins in the central and upper Nakdong River, the Sumjin River, and the Youngsan River exhibit decreases in runoff between -16 and $-23 \%$. This is the combined result of a decrease in annual mean precipitation and an increase in evapotranspiration. Evapotranspiration substantially increases $(+7$ to $+20 \%$ ) as the annual mean temperature rises by $2.7^{\circ} \mathrm{C}$. In 2061 to 2090, despite the increase in annual mean precipitation, the annual mean runoff was projected to decrease by $14 \%$ in most basins except the central and lower catchments of the Han River, the east coast, and lower catchments of the Nakdong River basin. In general, runoff in Korea is expected to increase in northern regions and decrease in southern regions, with more variability in northern regions. These results indicate that the supply of water resources may be more vulnerable in sub-basins located in the southern region.

\subsection{Changes in seasonal runoff}

The discharge of sub-basins in Korea shows intense seasonality mainly due to the summer monsoon climate. A change in the magnitude and timing of seasonal runoff could exacerbate the difficulties that already exist in developing water resource management policies. In particular, a change in runoff during the spring and summer seasons is closely related to droughts and flooding in this region. Therefore, it is important to evaluate the seasonal variations of runoff and how these may be impacted by climate change. We analyzed the relative changes in seasonal mean runoff in the 5 large river basins. The seasonal periods include summer (June, July, and August) and winter (December, January, and February) together and spring (March, April and May) and autumn (September, October, and Novem- 

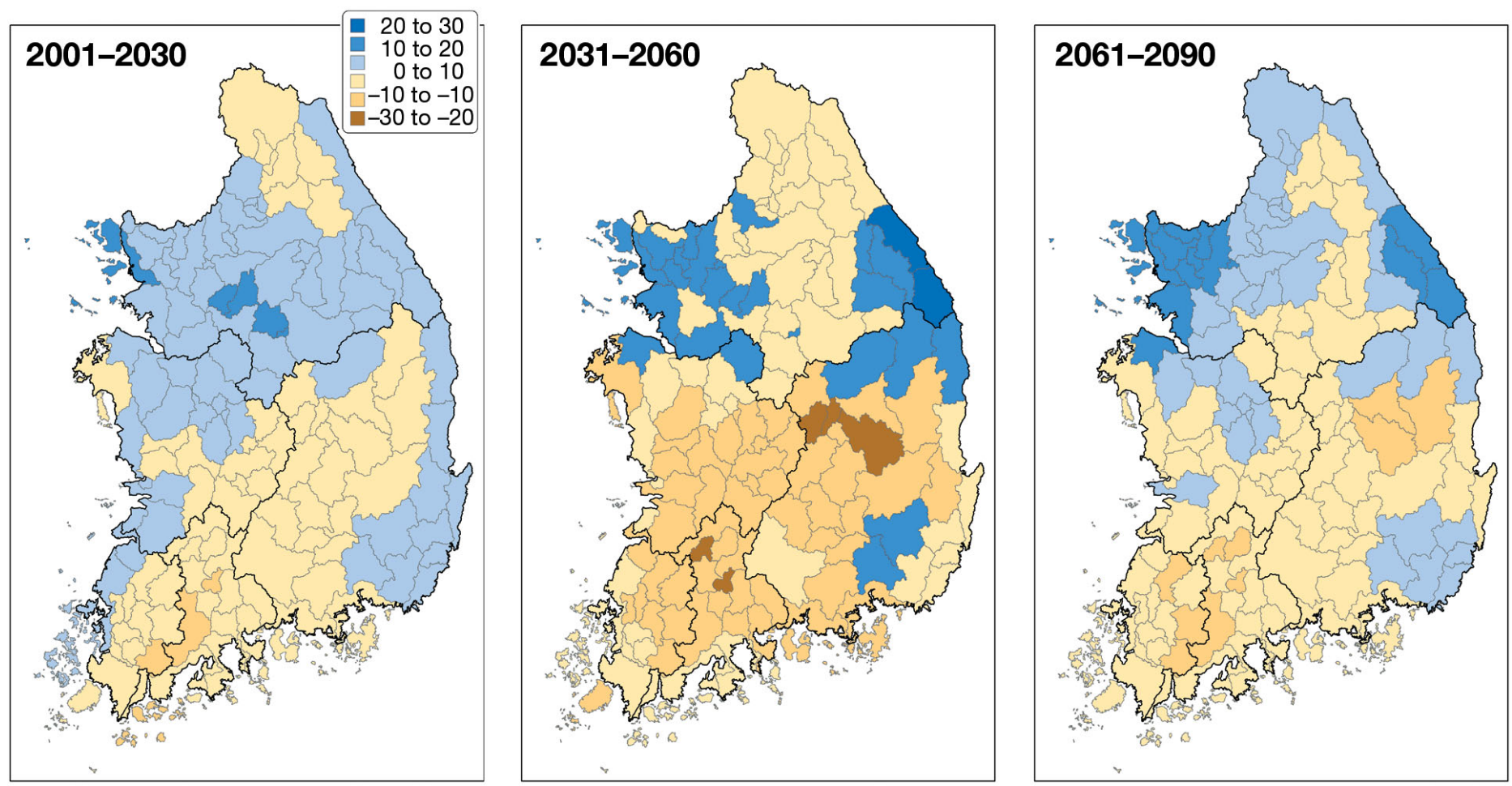

Fig. 5. Relative changes (\%) of runoff during 2001 to 2030, 2031 to 2060 and 2061 to 2090 relative to the reference period under the A2 scenarios in Korean sub-basins

ber) together (Fig. 6). The results show significant trends in increased runoff during autumn and winter and decreased runoff during spring and summer in most basins. In addition, the magnitude of seasonal runoff change increases in 2031 to 2060 and 2061 to 2090 as compared to 2001 to 2030. This increasing seasonal variability suggests that water resources management (in terms of water supply and/or flood protection) may be increasingly affected by climate change in the future.

In most basins, the mean runoff in summer decreases in 2031 to 2060. The range of change in mean runoff in each season is highest in winter $(-2.69$ to $+176.3 \%)$. In the seasonal analysis, as for the annual mean runoff, the range of the change rate differs according to basins. In the case of the Han River sub-basins, those on the east coast and in the lower reaches of the river show increases in the summer runoff, while the remaining basins show decreases. In the Nakdong River sub-basins the change in the summer season runoff during 2031 to 2060 shows the largest decrease $(-44.1 \%)$. The basins in the northern part of Korea (e.g. the Han and Gum River basins) exhibit similar seasonal change tendencies. The basins in the sourthern part of the country (Nakdong River, Sumjin River and Youngsan River basins) also show similar seasonal change tendencies.

\subsection{Water balance changes}

The water balance of a drainage basin is largely made up of precipitation, evapotranspiration, runoff, and soil water storage. Climate change is expected to directly affect precipitation and evapotranspiration, which could cause alterations in runoff and groundwater storage. Therefore, it is important to analyze the changes in the water balance in order to understand how runoff would be affected. In the present study, we evaluated changes in precipitation and evapotranspiration in each basin and analyzed their effect on runoff.

As shown in Fig. 7, the change in annual mean precipitation for each period was: -5 to $+10 \%$ (2001 to 2030), -6 to $+15 \%$ (2031 to 2060 ) and +1 to $+20 \%$ (2061 to 2090). Ninety-two sub-basins (66\%) showed increases in annual mean precipitation for 2001 to 2030, 68 (49\%) for 2031 to 2060 and 139 (100\%) for 2061 to 2090. The actual evapotranspiration (AET) obtained from the PRMS model was calculated from potential evapotranspiration $\times$ the rate factor (Hamon_coef; see Table 1). In all basins, as temperature rises, evapotranspiration also showed increases between 3 and $7 \%$ in the 2001 to 2030 period, between 7 and $20 \%$ in the 2031 to 2060 period, and between 12 and $36 \%$ in the 2061 to 2090 period. The inland watersheds showed larger temperature changes than watersheds in coastal regions. The annual mean water balance changes for each basin were -12 to $+14 \%$ (2001 

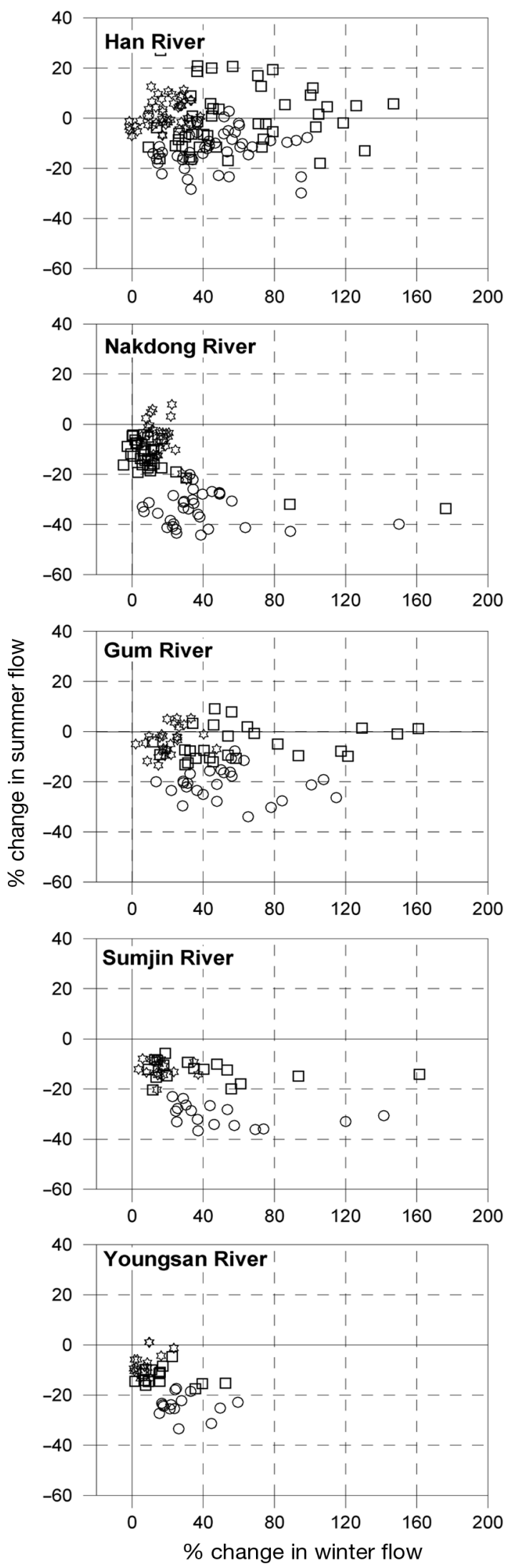
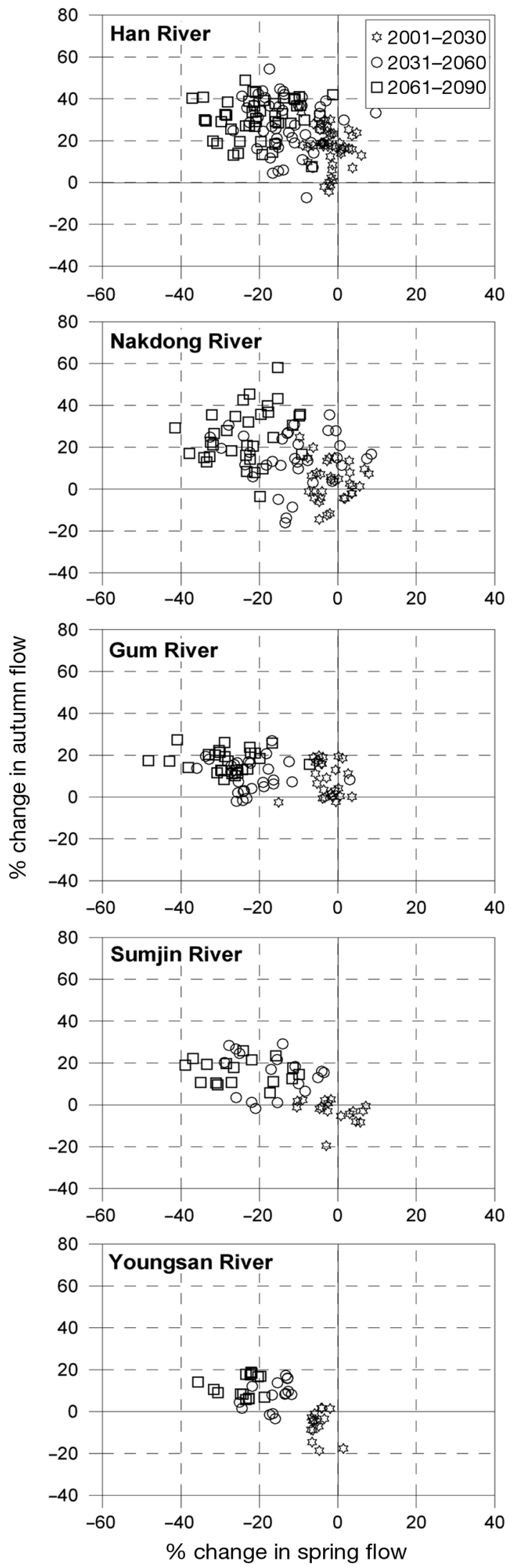

Fig. 6. Seasonal runoff variations under A2 scenarios 


\section{Precipitation}

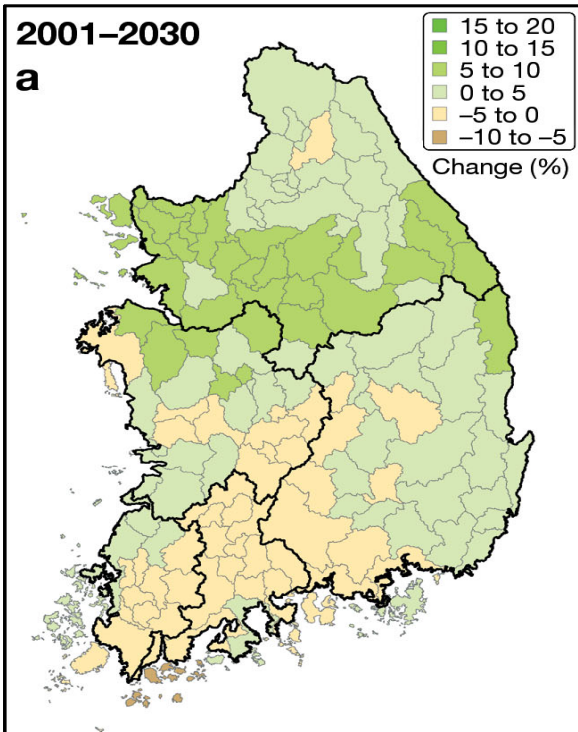

\section{Evapotranspiration}

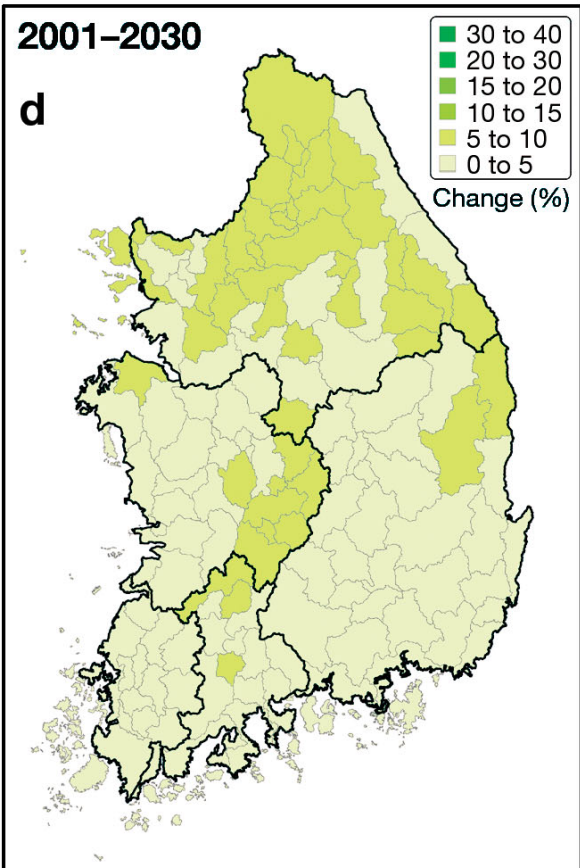

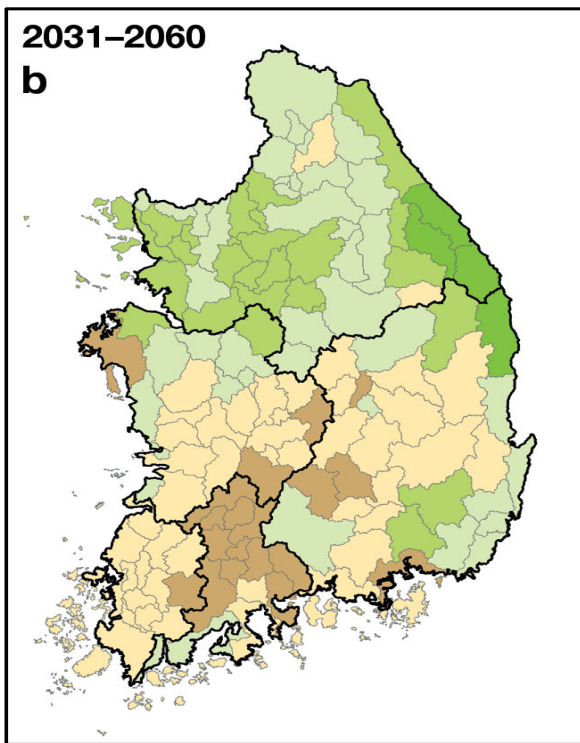
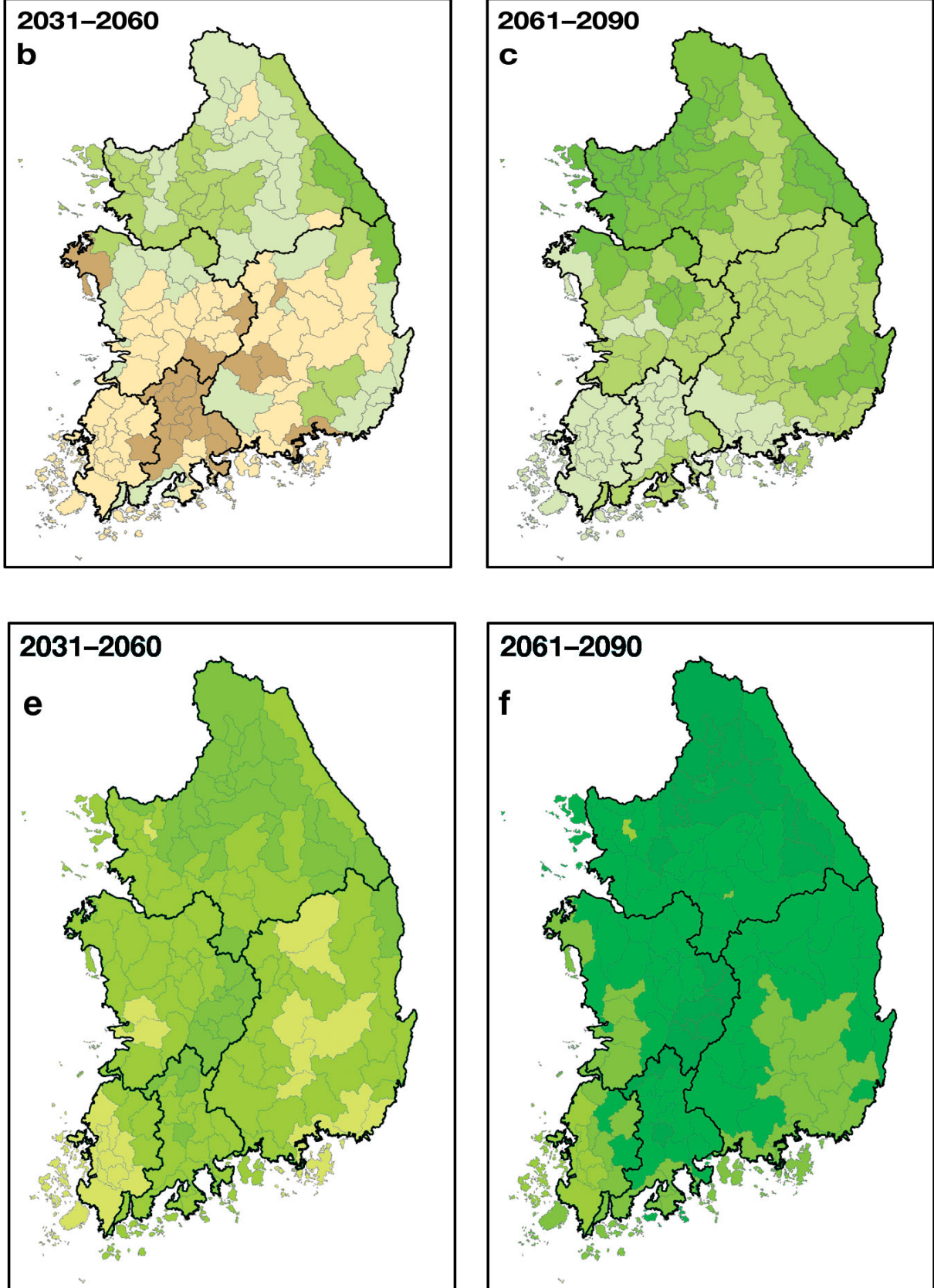

Fig. 7. Relative variations (\%) of $(\mathrm{a}-\mathrm{c})$ annual mean precipitation and $(\mathrm{d}-\mathrm{f})$ actual evapotranspiration during (a,d) 2001 to 2030 , (b,e) 2031 to 2060 and $(\mathrm{c}, \mathrm{f}) 2061$ to 2090 relative to the reference period

to 2030 ), -23 to $+16 \%$ (2031 to 2060 ) and -14 to $+20 \%$ (2061 to 2090). In addition, 69 sub-basins (50\%) showed decreases in water balance for 2001 to 2030, 113 (81\%) for 2031 to 2060 and 86 (62\%) for 2061 to 2090.

For each of the 5 major river basins, the amount of change for each water balance component, including annual mean precipitation, runoff, AET, and soil water storage, was compared for each period (Fig. 8). The annual mean evapotranspiration continually in- creased, while precipitation showed increases and decreases in consecutive periods in all basins. In the Nakdong, Sumjin and Youngsan River basins, despite the increase of precipitation in the 2061 to 2090 period, there was a projected decrease in runoff because of the increase in evapotranspiration as compared to the reference period. Thus, although precipitation may eventually increase due to climate change, water resources in some regions may not be abundant. 

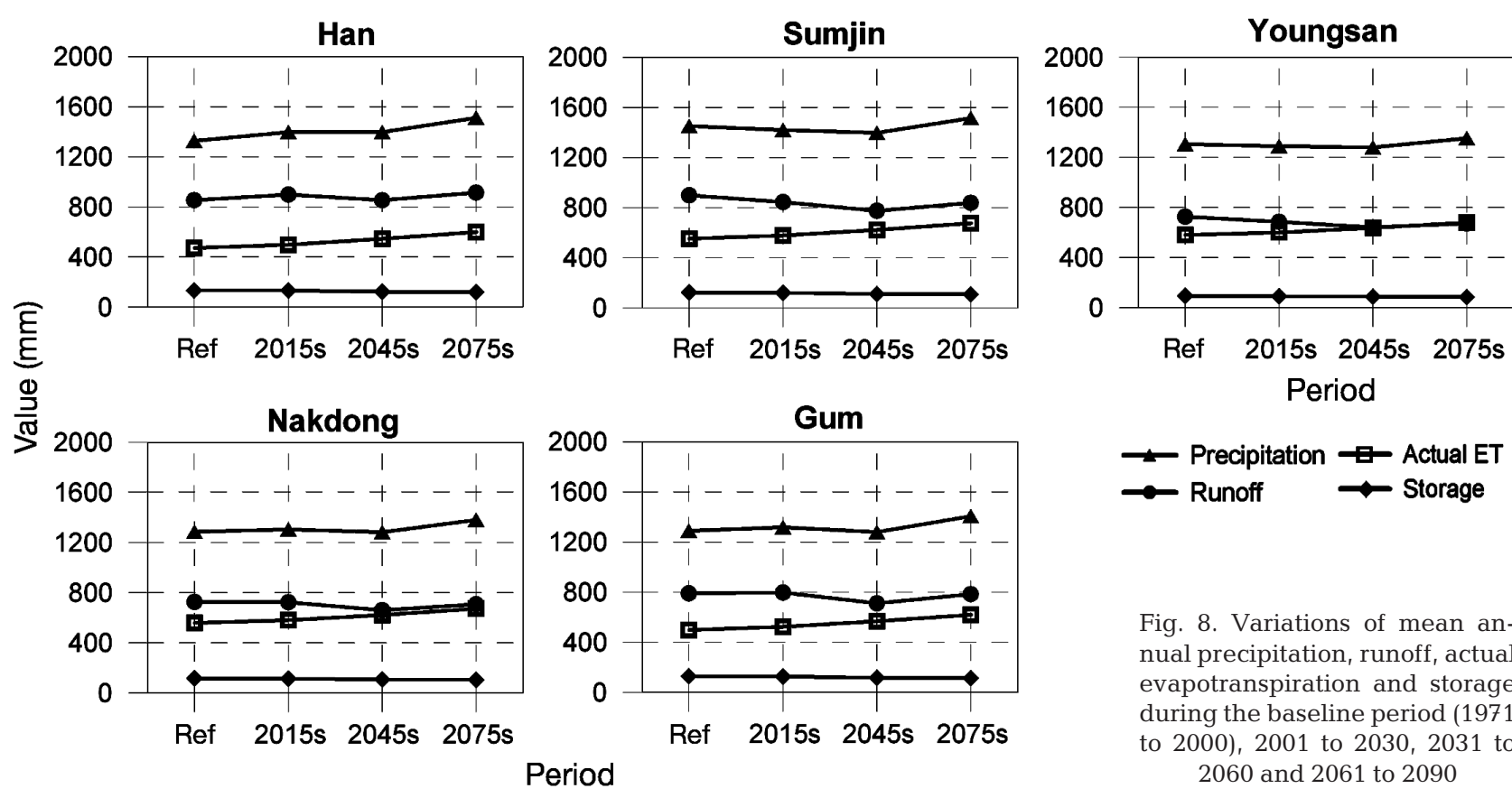

\section{DISCUSSION AND CONCLUSIONS}

Climate change is expected to increase uncertainty in the development of future water resources planning and management worldwide (IPCC 2007). In Korea, which has large regional differences and specific seasonality in river discharge, climate change may seriously affect regional water resources. Thus, it is necessary to estimate the impact of climate change on water resources at a regional scale to determine effective adaptation measures. The greatest advantage of using RCMs in hydrological studies is that the high-resolution data (spatial and temporal) can be obtained from these physically based models (Ekström et al. 2005). However, as shown in Fig. 4, there are limitations to applying RCM results directly to water-resource impact assessments at the catchment scale. Thus, we applied LARS-WG to overcome the limitations of the RCM. From our results, it can be seen that the climate data produced by LARS-WG better reflects regionspecific climate characteristics. To estimate the PRMS model parameters for ungauged catchments, the regionalization method was applied. Results show that the estimated model parameters are relatively reliable even for ungauged catchments (Table 5).

A number of studies have assessed the regional climate change impact on water resources (e.g. Bueh et al. 2003, Graves \& Chang 2007). These studies have shown increasing spatial and temporal variabilities of water resources under changing climate conditions. The results of our analysis are in agreement with these studies. In 2061 to 2090, annual mean precipitation is projected to increase in all of the Korean basins, but the annual mean runoff shows a decrease in many basins (in the upper and the middle Nakdong River and in the Gum, Sumjin, and Youngsan River basins) as compared to the reference period. This is a result of increases in evapotranspiration, as temperature is expected to increase by more than $4.0^{\circ} \mathrm{C}$ on average (Fig. 7) (an increase in evapotranspiration decreases moisture in the soil, causing a reduction of river flow, and increasing concentration of pollutants).

Climate change may result in more extreme events in Korea, including floods and droughts. In particular, spring seasons-which are expected to show a decrease in precipitation-have already shown increased agricultural and ecological damage from spring droughts (Kwon et al. 2006). In summer seasons, which already have frequent floods in Korea, mean seasonal runoff is projected to decrease. However, this does not necessarily represent a decrease in flood occurrences. Because most flooding depends not only on the quantity of precipitation but also on the frequency and intensity of precipitation, it would be difficult to project flood damage solely based on the amount of summer precipitation. Indeed, there is empirical evidence of a significant increase in the frequency of heavy summer precipitation events in the central part of Korea between 1973 and 2005 (Chang \& Kwon 2007). To evaluate the occurrence of extreme floods, it is necessary to include some kind of frequency analysis in the study (Leander et al. 2005). Investigating changes in the occurrence of extreme events under various climate change scenarios will be a subject of our continuing research. 
The increasing spatial variability of runoff also suggests the need to adopt different regional water resource management strategies. Basins located in the northern part of Korea are projected to experience increases in annual mean runoff, while basins in the southern region are expected to have decreases (Fig. 5). The southern region is largely cultivated for growing rice, so the decrease in the annual mean output quantity would have a negative effect on agricultural productivity. Thus, for the southern part of Korea, it is necessary to increase reservoir storage and implement improvements in irrigation technology. At the river basin scale, however, the projection of changes in water balance terms and runoff for 2001 to 2030 will be affected by the initial conditions of the ECHAM4 ensemble member used for the downscaling, and by natural climate variability.

When applying the results of our analysis to future water-resource planning and management policy, a few caveats should be borne in mind. (1) Our findings are based on one GCM simulation, and the simulation provides a small subset of possible outcomes. Future studies should include ensemble simulations developed from a number of different GCMs that are based on different greenhouse gas emission scenarios (Jasper et al. 2004). (2) Our results contain a measure of uncertainty from both downscaling methods (Schmidli et al. 2007) and hydrologic models (Wilby 2006) used for impact assessment. Quantifying these uncertainties should be the priority of future studies on the effects of climate change on water resources. (3) Future regional assessment of the vulnerability of water resources to climate change should include indicators of economic, social and environmental systems, and public health (Hurd et al. 1999). Water-resource systems could also be equally vulnerable to population growth or economic development (Chang et al. 2007).

By incorporating climate information in waterresources decision making, water-resource systems could become more resilient to potential climate stresses. Thus, there is a need for proper adaptation measures, based on an analysis of current conditions in basin-wide water-resource systems on the one hand, and of the vulnerability of socio-environmental elements on the other. While simple vulnerability assessments using empirical data could provide some insights for adaptive water-resource planning, the topdown approach used in the present study provides the additional benefits by revealing the hydrologic processes of potential spatial and temporal changes in water-resource systems.

Acknowledgements. This research was supported by Grant 1-9-3 from Sustainable Water Resources Research Center of the 21st Century Frontier Research Program. We thank
Dr. Won-Tae Kwon of METRI for providing high-resolution MM5 climate change simulations. The constructive comments from three anonymous reviewers greatly improved the clarity of the manuscript.

\section{LITERATURE CITED}

Ahn JH, Yoo C, Yoon YN (2001) An analysis of hydrologic changes in Daechung dam basin using a GCM simulation results due to global warming. J Korea Water Resour Assoc 34(4):335-345 (in Korean)

Arnell NW (2004) Climate change and global water resources: SRES emissions and socio-economic scenarios. Global Environ Change 14:31-52

Atkinson SE, Woods RA, Sivapalan M (2002) Climate and landscape controls on water balance model complexity over changing timescales. Water Resour Res 38(12):1314 doi: 10.1029/2002WR001487

Bae DH, Jung IW, Chang H (in press) Long-term trends of precipitation and runoff in Korean river basins. Hydrol Process

Bergström S, Carlsson B, Gardelin M, Lindström G, Pettersson A, Rummukainen M (2001) Climate change impacts on runoff in Sweden-assessments by global climate models, dynamical downscaling and hydrological modelling. Clim Res 16:101-112

Beven KJ (2000) Uniqueness of place and process representations in hydrological modelling. Hydrol Earth Sys Sci 4(2):203-213

Bueh C, Cubasch U, Hagemann S (2003) Impacts of global warming on changes in the East Asian monsoon and the related river discharge in a global time-slice experiment. Clim Res 24(1):47-57

Chang H, Kwon WT (2007) Spatial variations of summer precipitation trends in South Korea, 1973-2005. Environ Res Lett 2:045012, doi: 10.1088/1748-9326/2/4/045012

Chang H, Franczyk J, Im ES, Kwon WT, Bae DH, Jung IW (2007) Vulnerability of Korean water resources to climate change and population growth. Water Sci Technol 56: $57-62$

Dagnachew L, Christine VC, Francoise G (2003) Hydrological response of a catchment to climate and land use changes in tropical Africa: case study south central Ethiopia. J Hydrol 275:67-85

Drogue G, Pfister L, Leviandier T, El Idrissi A, Iffly JF, Matgen P, Humbert J, Hoffmann L (2004) Simulating the spatiotemporal variability of streamflow response to climate change scenarios in a mesoscale basin. J Hydrol 293: 255-269

Ekström M, Fowler HJ, Kilsby CG, Jones PD (2005) New estimates of future changes in extreme rainfall across the UK using regional climate model integrations. II. Future estimates and use in impact studies. J Hydrol 300(1-4): 234-251

Fowler A (1999) Potential climate change impacts on water resources in the Auckland Region (New Zealand). Clim Res 11:221-245

Graves D, Chang H (2007) Hydrologic impacts of climate change in the Upper Clackamas River basin, Oregon, USA. Clim Res 33(2):143-157

Guo S, Wang J, Xiong L, Ying A, Li D (2002) A macro-scale and semi-distributed monthly water balance model to predict climate change impacts in China. J Hydrol 268:1-15

Hamon WR (1961) Estimating potential evapotranspiration. Proc Am Soc Civil Eng J Hydraulic Division 87(HY3): $107-120$ 
Hay LE, Clark MP, Wilby RL, Gutowski WJ, Leavesley CH, Pan Z, Arritt RW, Takle ES (2002) Use of regional climate model output for hydrologic simulations. J Hydrometeorol 3:571-590

Hong SY, Juang HM (1998) Orography blending in the lateral boundary of a regional model. Mon Weather Rev 126: $1714-1718$

Hurd B, Leary N, Jones R, Smith J (1999) Relative regional vulnerability of water resources to climate change. J Am Water Resour Assoc 35(6):1399-1409

IPCC (Intergovernmental Panel on Climate Change) (2007). Climate change 2007: the physical science basis. Contribution of WG I to the fourth assessment report of the Intergovernmental Panel on Climate Change, Cambridge University Press, Cambridge. Available at: http://ipcc-wg1. ucar.edu/wg1/wg1-report.html

Jasper K, Calanca P, Gyalistras D, Fuhrer J (2004) Differential impacts of climate change on the hydrology of two alpine river basins. Clim Res 26(2):113-129

Jung IW, Bae DH (2005a) A study on PRMS applicability for Korean river basin. J Korea Water Resour Assoc 38(9): 713-725 (in Korean)

Jung IW, Bae DH (2005b) Regionalization of a continuous runoff model parameters based on basin physical characteristics. In: Jun et al. (ed) Int Assoc Hydraul Eng Res (IAHR) 31st Congr, Seoul. Korea Water Resources Association 1:302-309

Jung IW, Bae DH, Im ES (2007) Generation of high resolution scenarios for climate change impacts on water resources. II. Runoff scenarios on each sub-basins. J Korea Water Resour Assoc 40(3):205-214 (in Korean)

Khan MS, Coulibaly P, Dibike Y (2006) Uncertainty analysis of statistical downscaling methods using Canadian Global Climate Model predictors. Hydrol Process 20(14):3085-3104

Kim YO, Seo YW, Lee DR, Yoo C (2005) Potential effects of global warming on a water resources system in Korea. Water Int 30:400-405

Koren VI, Smith M, Wang D, Zhang Z (2000) Use of soil property data in the derivation of conceptual rainfall-runoff model parameters. Paper 2.16, 15th Conf Hydrol, Am Meteorol Soc, Long Beach, CA, p 103-106

Kwon HJ, Park HJ, Hong DO, Kim SJ (2006) A study on semidistributed hydrologic drought assessment modifying SWSI. J Korea Water Resour Assoc 39(8):645-658 (in Korean)

Lamb R, Calver A (2002) Continuous simulation as a basis for national flood frequency estimation. In: Littlewood I (ed) Continuous river flow simulation: methods, applications and uncertainties. Occasional Paper No. 13, British Hydrological Society, Wallingford, p 67-75. Available at: http:// www.hydrology.org.uk/publications/BHS_OP13x.pdf

Leander R, Buishand A, Aalders P, Wit MD (2005) Estimation of extreme floods of the River Meuse using a stochastic

Editorial responsibility: Gerd Esser,

Gießen, Germany weather generator and a rainfall-runoff model. Hydrol Sci J 50(6):1089-1103

Leavesley GH, Lichty RW, Troutman BM, Saindon LG (1983) Precipitation-Runoff Modeling System: user's manual. Water-Resour Investig Report 83-4238:1-207

Leavesley GH, Markstrom SL, Restrepo PJ, Viger RJ (2002) A modular approach to addressing model design, scale, and parameter estimation issues in distributed hydrological modeling. Hydrol Process 16(2):173-187

Legutke S, Maire-Reimer E (1999) Climatology of the HOPEG global ocean general circulation model. DKRZ Technical Report No. 21, Deutsches Klimarechenzentrum, Hamburg

Merz B, Blöschl G (2004) Regionalisation of catchment model parameters. J Hydrol 287(1-4):95-123

METRI (METeorological Research Institute, Korea) (2004) Research on the development of regional climate change scenarios to prepare the national climate change. III. METeorological Research Institute, Seoul (in Korean)

Milly PCD, Dunne KA, Vecchia AV (2005) Global pattern of trends in streamflow and water availability in a changing climate. Nature 438 (7066):347-350

MOCT (Ministry of Construction and Transportation, Korea) (2001) Water vision 2020. Ministry of Construction and Transportation, Seoul (in Korean)

PAI (Population Action International) (1993) Sustaining water population and the future of renewable water supplies. In: Engelman R, Leroy P (eds) Sustaining water, easing scarcity. Population Action International, Washington, DC

Pilling C, Jones JAA (1999) High resolution climate change scenarios: implications for British runoff. Hydrol Process 13:2877-2895

Rosenbrock HH (1960) An automatic method of finding the greatest or least value of a function. Comput J 3:175-184

Schmidli J, Goodess CM, Frei C, Haylock MR, Hundecha Y, Ribalaygua J, Schmith T (2007) Statistical and dynamical downscaling of precipitation: an evaluation and comparison of scenarios for the European Alps. J Geophys Res 112(D4):D04105, doi: 10.1029/2005JD007026

Semenov MA, Barrow EM (2002) A stochastic weather generator for use in climate impact studies: user manual. Rothamsted Research, Harpenden. Available at: http:// www.rothamsted.ac.uk/mas-models/download/LARS-WGManual.pdf

Thiessen AH (1911) Precipitation averages for large areas. Mon Weather Rev 39:1082-1084

Wagener T, Wheater HS (2006) Parameter estimation and regionalization for continuous rainfall-runoff models including uncertainty. J Hydrol 320:132-154

Wilby RL (2006) Uncertainty in water resource model parameters used for climate change impact assessment. Hydrol Process 19:3201-3219

Submitted: March 10, 2007; Accepted: August 28, 2007

Proofs received from author(s): December 25, 2007 